\title{
Regulatory T Cell Immunotherapy in Immune-Mediated Diseases
}

\author{
Antonio Pierini $^{1,2} \cdot$ Dominik Schneidawind ${ }^{1,3} \cdot$ Hidekazu Nishikii ${ }^{1,4} \cdot$ Robert S. Negrin $^{1}$
}

Published online: 12 September 2015

(C) Springer International Publishing AG 2015

\begin{abstract}
Broad clinical interest rapidly followed the recent discovery of different subpopulations of $\mathrm{T}$ cells that have immune regulatory properties, and a number of studies have been conducted aiming to dissect the translational potential of these promising cells. In this review, we will focus on forkhead box P3 (FoxP3) positive regulatory T cells, T regulatory type 1 cells, and invariant natural killer $\mathrm{T}$ cells (iNKT). We will analyze their ability to correct immune dysregulation in animal models of immune-mediated diseases, and we will examine the first clinical approaches where these cells have been directly or indirectly employed. We will discuss successes, challenges, and limitations that rose in the road to the clinical use of regulatory $\mathrm{T}$ cells.
\end{abstract}

Keywords $\mathrm{FoxP}^{+}{ }^{+}$T regulatory cells $\cdot$ T regulatory type 1 cells $\cdot$ Invariant natural killer T cells $\cdot$ Hematopoietic stem cell transplantation · Graft versus host disease $\cdot$ Tolerance induction

This article is part of the Topical Collection on Cellular Therapies: Preclinical and Clinical.

Antonio Pierini, Dominik Schneidawind and Hidekazu Nishikii equally contributed to the preparation of the manuscript.

Robert S. Negrin

negrs@stanford.edu

1 Blood and Marrow Transplantation, Stanford University School of Medicine, Center for Clinical Sciences Research Building, Room 2205, 269 Campus Drive, Stanford, CA 94305, USA

2 Hematology and Clinical Immunology, Department of Medicine, University of Perugia, Perugia, Italy

3 Department of Medicine II, Eberhard Karls University, Tübingen, Germany

4 Department of Hematology, Faculty of Medicine, University of Tsukuba, Tsukuba, Japan

\section{Introduction}

The discovery of regulatory $\mathrm{T}$ cells (Treg) and their immunoregulatory and tolerogenic properties led to a broad range of biological studies with the hope of developing new treatments for several immune-mediated diseases. Different subsets of Treg have been described. In this review, we will focus on forkhead box P3 (FoxP3) positive T regulatory cells (FoxP3 ${ }^{+}$Treg), T regulatory type 1 cells $(\mathrm{Tr} 1)$, and invariant natural killer $\mathrm{T}$ cells (iNKT). These Treg populations have been widely studied for their suppressive activity in different immune responses and animal models of disease. We will discuss the most recent clinical therapeutic approaches with the use of these cells in immune-mediated diseases.

\section{Biology of FoxP3 ${ }^{+}$Treg, Tr1, and iNKT Cells}

FoxP3 ${ }^{+}$Treg are a subset of $\mathrm{CD} 4{ }^{+} \mathrm{T}$ cells that possess potent suppressive activity by impacting the proliferation and function of several cell populations such as T, B, NK, and antigenpresenting cells [1]. FoxP3 ${ }^{+}$Treg are characterized by the expression of the nuclear transcription factor FoxP3 that is crucial for the maintenance of immune tolerance in animal models and human diseases [2-5]. Another important marker of FoxP3 $3^{+}$Treg is $\mathrm{CD} 25$, the alpha subunit of the interleukin-2 (IL-2) receptor. These cells express CD25 at high level making them extremely sensitive to IL-2, yet interestingly, Treg do not produce this cytokine [6]. Furthermore, CD25 expression allows for selection and purification of FoxP $3^{+}$Treg in preclinical and clinical studies [7]. Human and mouse FoxP3 $3^{+}$ Treg have different phenotypic characteristics and function trough several mechanisms that may vary according to the settings in which these cells have been studied or are utilized. Several studies have shown that cytokine production is 
required for suppressive function. The main cytokines in this context are interleukin-10 (IL-10), transforming growth factor beta (TGF- $\beta$ ), and interleukin-35 (IL-35) [8-11]. Other mechanisms of FoxP3 ${ }^{+}$Treg function require cell-to-cell contact and involve expression of different molecules such as CTLA-4, LAG-3, CD39, perforin, and granzymes [12-17].

$\operatorname{Tr} 1$ cells are a population of $\mathrm{T}$ lymphocytes characterized by the secretion of high levels of IL-10, minimal amounts of interleukin-4 (IL-4) and 17 (IL-17), and low expression of FoxP3 [18-24]. IL-10 production peaks at $12-24 \mathrm{~h}$ after activation [19]. Tr1 cells can be detected in vivo in patients that are tolerant to donor stem cell grafts [18, 20,25], and recently, a distinct phenotype has been described for these cells, as they constitutively express LAG-3 and CD49b [26•]. Tr1 cells have the ability to modulate different immune responses producing and secreting IL-10 and TGF- $\beta$, and require T cell receptor (TCR) stimulation to exert their suppressive function even if their growth and proliferation is TCR independent [27].

In humans and mice, iNKT cells are characterized through the expression of the semi-invariant TCRs $\mathrm{V} \alpha 24-\mathrm{J} \alpha 18$ and $\mathrm{V} \alpha 14-\mathrm{J} \alpha 18$, respectively. TCR activation through glycolipids that are presented by the major histocompatibility complex (MHC)-I like molecule CD1d results in an instant effector function characterized by the rapid release of cytokines such as IFN- $\gamma$, IL-4, and IL-13 [28, 29]. A growing body of preclinical animal models and recent clinical trials suggest that iNKT cells play a central role in promoting sustained immunologic tolerance through a well-balanced interaction with myeloid-derived suppressor cells (MDSCs) and Treg even if the underlined mechanisms have been not fully elucidated.

\section{Treg Adoptive Transfer in Hematopoietic Stem Cell Transplantation}

Hematopoietic stem cell transplantation (HSCT) is an effective therapy for a range of hematological malignancies, genetic disorders, bone marrow failure states, and for the induction of solid organ transplantation tolerance. A major risk following HSCT is graft versus host disease (GvHD) that is a potentially lethal immune-mediated disease. GvHD is the major cause of transplant-related mortality (TRM); therefore, much effort has been extended to prevent and improve treatment of this complication. As GvHD is triggered by immune reactions against host antigens, FoxP3+ Treg immediately became a potential therapeutic tool because of their ability to regulate and modulate immune responses and control $\mathrm{T}$ cell proliferation [30]. Preclinical studies have demonstrated that FoxP3+ Treg adoptive transfer can prevent GvHD while maintaining graft versus tumor $(\mathrm{GvT})$ effects opening the doors to clinical translation [7, 31-34]. The first study that reported FoxP3+ Treg adoptive transfer for the treatment of GVHD was a report of two cases by Trzonkowski et al. where two transplanted patients with hematologic malignancies were treated with in vitro expanded $\mathrm{CD} 4^{+} \mathrm{CD} 25^{+} \mathrm{CD} 127^{-}$Treg. One patient with chronic GvHD (cGvHD) received a single dose of $1 \times$ $10^{5} / \mathrm{kg}$ Treg that induced clinical improvement and allowed for reduction in steroid dose. The second patient with severe acute GvHD (aGvHD) received three doses for a total of $3 \times$ $10^{6} / \mathrm{kg}$ FoxP3 + Treg obtaining only a transient improvement and that patient ultimately died of progressive disease [35]. Limitations in the Treg preparation of this small study were the paucity of the cells and final Treg purity after expansion. A larger study from Di Ianni et al. demonstrated that the adoptive transfer of freshly isolated $\mathrm{CD} 4{ }^{+} \mathrm{CD} 25^{+}$Treg can effectively prevent GvHD in the haploidentical transplantation setting. In this study, the authors reported a low incidence of acute and cGvHD (2/26 treated patients) despite the infusion of $1 \times 10^{6}$ / $\mathrm{kg}$ donor conventional $\mathrm{T}$ cells (Tcon) without immunosuppression. Even though GvHD was reduced by Treg treatment, TRM was still relatively high (13/26 patients) due to the toxicity of the preparative regimen and infections [36 ]. Recently, the same group reported an update of their clinical trial where they showed that FoxP3+ Treg plus Tcon adoptive immunotherapy resulted in a low rate of GvHD incidence and also very few relapses indicating retention of GvT effects in the clinic. In this study, the reported relapse rate was reduced in comparison to a historical control group, and only two of 41 patients with high risk acute leukemias who were treated with FoxP3 + Treg and Tcon relapsed with a median follow-up of 46 months [37]. Encouraging results were also reported by Brunstein et al. in Minnesota, USA, where they used umbilical cord blood ex vivo expanded third party FoxP3+ Treg for GvHD prevention in the setting of double cord transplantation. They demonstrated that FoxP3+ Treg expansion is feasible and safe, and FoxP3 + Treg infusion appeared to reduce GvHD in 23 patients compared to a control group of patients that received similar conditioning and immunosuppressive therapy [38]. In the cGvHD setting, the group from Dresden, Germany, recently reported the results from a small trial in which they infused $\mathrm{CD} 4^{+} \mathrm{CD} 25^{+}$in vitro expanded Treg to five patients with treatment-refractory cGvHD. The Treg infusion was well tolerated and induced clear improvement in cGvHD symptoms in two patients, while the other three had stable disease [39]. All these studies taken together strongly support the clinical use of FoxP3 ${ }^{+}$Treg for GvHD prevention and possibly for GvHD treatment demonstrating safety and feasibility and providing insights on efficacy. The different cell selection and purification methods and the diverse treatment protocols used leave a number of questions unanswered regarding the best approach to use in the different clinical settings.

$\operatorname{Tr} 1$ cells have been recently described as a possible alternative to Fox $3^{+}$Treg, but the main limitation to their clinical use in the past years has been the lack of a clear phenotype that could be used for purifying the cell population. Tr1 cells are 
induced by in vitro treatment with IL-10 of the whole T cell pool in the presence of alloantigens that enriches for alloantigen-specific $\operatorname{Tr} 1$ cells and promotes $\mathrm{T}$ cell anergy $[20,40,41]$. Bacchetta et al. reported results from the first clinical study conducted in Milan, Italy, where IL-10 "anergized" donor lymphocytes in the presence of host antigen presenting cells were infused into patients to promote immune reconstitution after haploidentical transplantation. These cells appeared to promote immune reconstitution in the absence of relapse, in 4 of 12 treated patients, however, grade II/III aGvHD was observed [42]. The phenotypic characterization of $\operatorname{Tr} 1$ cells that have been recently defined as LAG3 + and CD49b+ will be extremely helpful for purification of these suppressive cells promoting their clinical application $\left[26^{\bullet}\right]$.

\section{Interleukin-2 Treatment for Promoting Treg In Vivo Function}

The paucity of Treg in the peripheral blood and the complexity of isolating this rare cell population have limited their clinical application [30, 43]. One strategy to overcome this challenge is to develop approaches to activate and expand Treg in vivo. As discussed above, $\mathrm{FoxP}^{+}$Treg require IL-2 for their development, survival, and activation $[6,44,45]$. Treatment with low-dose IL-2 was safe and did not increase GvHD rates in haploidentical HSCT, while it promoted an increase in Treg number $[46,47]$. Koreth et al. demonstrated that low-dose IL2 is safe and can improve symptoms of cGvHD in a phase I clinical trial. Low-dose IL-2 induced a partial response of cGvHD in 12 of 23 patients that were evaluable for response assessment and induced a marked increase in the Treg/Tcon ratios and in the absolute numbers of FoxP $3^{+}$Treg [48]. The same group also demonstrated that low-dose IL-2 therapy selectively impacts FoxP3 ${ }^{+}$Treg and restores CD4+ T cell homeostasis that is unbalanced in cGvHD favoring immune tolerance [49].

Low-dose IL-2 has also been demonstrated to be effective in increasing FoxP3 ${ }^{+}$Treg number in different clinical settings. Saadoun et al. recently published the results from a phase I/II clinical trial with the use of low-dose IL-2 in refractory $\mathrm{HCV}$-induced vasculitis that is a disease sustained by autoimmune mechanisms. IL-2 was able to expand FoxP3 ${ }^{+}$ Treg resulting in an improvement of clinical signs and symptoms in 8 of 10 treated patients [50]. Furthermore, low-dose IL-2 therapy has been used in patients with type 1 diabetes (T1D). Treg play an important role in the pathophysiology of T1D, and preclinical studies showed that IL-2 treatment can prevent and reverse hyperglycemia through $\mathrm{FoxP}^{+}$Treg activation and expansion resulting in prevention of spontaneous and recurring diabetes when used in combination with rapamycin [51-55]. In a phase I multicenter clinical trial, patients with T1D were treated with a course of rapamycin/ IL-2. Unfortunately, despite the safety of the treatment and a promising increase in Treg number with no modifications in other $\mathrm{T}$ cell subsets, treatment resulted in marked but transient $\beta$-cell dysfunction in all of the nine treated patients [56]. This negative result has been attributed to the potential effects of IL-2 on other immune cells, such as NK cells [57]. Another more recent phase I/II clinical study reported 24 patients affected by T1D treated with placebo or IL-2 at different doses $(0.33,1$, or $3 \mathrm{MIU} /$ day) for a course of 5 days. IL-2 treatment was generally safe and induced a selective increase in Treg number without having a negative impact on glucose metabolism. The short follow-up and treatment course do not permit evaluation of the efficacy of the approach [58].

In all these reports, IL- 2 treatment increased $\mathrm{FoxP}^{+}$Treg number and Treg/Tcon ratio in the peripheral blood of treated patients even if used at different doses with different courses. This selective effect on T cells appears to be the key mechanism of potential efficacy; however, the approach of low-dose IL-2-based therapy still needs to be proven by larger clinical trials.

\section{Treg In Vivo Targeting for Modulation of Immune Responses in the Treatment of Autoimmune Diseases}

Several animal models of autoimmune diseases demonstrated that autoimmune responses could be controlled by restoring the balance of effector T cells and Treg. In humans, the mutation of the FoxP3 gene results in a syndrome called IPEX (Immune dysregulation including type I diabetes, thyroiditis, severe allergy, inflammatory bowel disease, polyendocrinopathy, enteropathy, $\mathrm{X}$ linked) implying that FoxP3 ${ }^{+}$Treg have an important role in the pathogenesis of autoimmune disease [3]. Depletion of Treg in mice also induces organ-specific or systemic autoimmune diseases [59-61].

Examples of Treg-based therapy to treat autoimmune diseases include clinical trials in T1D. T1D results from immunemediated destruction of pancreatic beta cells leading to severe hyperglycemia and dependence on exogenous insulin administration. In the NOD mouse model, beta cell destruction is caused by autoreactive $T$ cells which recognize islet cell antigens and lead to beta cell destruction [62]. As above mentioned, the pilot study of combination therapy with IL-2 and rapamycin in T1D patients showed that treatment transiently worsened beta cell function although the number of Treg was temporarily increased [56, 57]. Marek-Trzonkowska et al. reported a preliminary study with Treg adoptive transfer in patients with T1D showing more promising results. They treated 10 T1D-affected children with injection of a high number $\left(10-20 \times 10^{6} / \mathrm{kg}\right)$ of autologous in vitro expanded $\mathrm{CD} 4^{+} \mathrm{CD} 25^{+} \mathrm{CD} 127^{-}$Treg obtaining a significant decrease 
in the requirement for exogenous insulin and an increase in Cpeptide levels in comparison to control children with similar disease characteristics during the short follow-up period [63].

A different therapeutic approach in T1D patients involves the use of CD3-specific monoclonal antibodies (teplizumab and otelixizumab) that showed preservation of beta cell function in a pilot clinical trial [64]. These drugs are thought to modulate the balance between pathogenic effector $\mathrm{T}$ cell and Treg. In the mouse model, CD3-specific monoclonal antibodies can preferentially remove the pathogenic $\mathrm{T}$ cell and relatively preserve the Treg population [62]. Samples from the antibody treated subjects suggested that the antibodies induced CD8+ cells with regulatory function [65]. Although further studies are required to optimize the dose and timing of treatment, some benefits from the $\mathrm{CD} 3$ antibodies have been already reported [66-68]. Another example of the immune therapy modulating Treg function is fingolimod, the first drug to modulate the sphingolipid signaling pathway for the treatment of patients with relapsing-remitting multiple sclerosis [69]. Sphingosine1-phosphate (S1P) signaling is associated with several physiological processes including $\mathrm{T}$ cell function. S1P signaling has been reported to play a role in Treg development [70]. Treg derived from S1P-deficient mice showed a greater capacity to suppress the proliferation of effector T cells. Conversely, overexpression of S1P led to a reduced number and activity of Treg [71]. These data suggested that S1P signaling is highly associated with Treg number/function, although fingolimod also regulates the migration and function of non-Treg populations and may directly affect neuronal cells [72].

A correlation was also made between FoxP3 ${ }^{+}$Treg and the pathophysiology of rheumatoid arthritis (RA) in patients that received anti-tumor necrosis factor (TNF) therapy. TNF was reported to inhibit the suppressive function of FoxP3 ${ }^{+}$Treg, and Treg isolated from RA patients showed poor suppressive activity of effector $\mathrm{T}$ cells. Treatment with the anti-TNF antibody (Infliximab) increased FoxP3 expression and restored their suppressive function [73]. These data suggested that the effect of anti-TNF therapy in RA patients is not only for the reduced level of TNF but also for the modulation of the number and function of Treg.

Clinical experience with $\operatorname{Tr} 1$ cells in autoimmune disease is limited to a pilot clinical trial in Crohn's disease (CD), where in vitro generated ovalbumin (OVA)-specific $\operatorname{Tr} 1$ cells were injected at different doses in $20 \mathrm{CD}$ patients that received an OVA-enriched diet to allow for homing to the gut of the OVAspecific $\operatorname{Tr} 1$ cells. This treatment induced a transient $40 \%$ response rate that is promising considering the limitations in cell number and selection [74].

These studies demonstrate that the complexity of immune interactions limits the translation of promising preclinical studies in autoimmune diseases; therefore, a better understanding of the precise role of Treg in the different settings is required to make Treg-based therapies a feasible and effective treatment option.

\section{iNKT and TLI/ATG Conditioning Promote Tolerance Induction}

iNKT cells are defined by the expression of the semi-invariant TCR $\mathrm{V} \alpha 24-\mathrm{J} \alpha 18$ in humans and $\mathrm{V} \alpha 14-\mathrm{J} \alpha 18$ in mice. Although iNKT cells constitute a small subset of lymphocytes, they are potent immunoregulators promoting immunologic tolerance through the rapid release of cytokines. iNKT cells upregulate the expression of antiapoptotic genes after radiation exposure resulting in relative radioresistance [75-77]. This biologic feature has been applied in the concept of reduced intensity conditioning with fractionated irradiation focusing on lymphoid tissues (total lymphoid irradiation) and the administration of antithymocyte globulin (TLI/ATG).

Early preclinical studies in mongrel dogs showed that TLI/ ATG conditioning promoted tolerance of heart allografts [78]. Subsequent murine studies revealed that this regimen was also associated with a reduced risk of GvHD [76]. Pillai et al. demonstrated that host iNKT cells promote an IL-4-dependent expansion of donor $\mathrm{CD} 4^{+} \mathrm{CD} 25^{+} \mathrm{FoxP}^{+}$Treg and that both host iNKT and donor Treg are required for the protection from GvHD in the setting of TLI/ATG conditioning [79]. Furthermore, Hongo et al. showed in a murine model of combined HSCT and heart transplantation after TLI/ATG conditioning that graft acceptance required host iNKT cells, $\mathrm{CD} 11 \mathrm{~b}^{+} \mathrm{Gr}-1^{+} \mathrm{MDSCs}$, and IL-10 producing Treg [80, 81]. Recently, van der Merwe et al. observed an increase of $\mathrm{CD} 11 \mathrm{~b}^{+} \mathrm{Gr}-1{ }^{\text {low }} \mathrm{CD} 11 \mathrm{c}^{+}$myeloid progenitors through $\mathrm{TLI} /$ ATG conditioning that require IL-4 signaling and the presence of host iNKT cells [82]. Our group showed recently in a myeloablative model of allogeneic HSCT that low numbers of adoptively transferred donor or third party $\mathrm{CD} 4^{+}$iNKT cells protect from GvHD lethality through an expansion of donor Treg which was associated with an expanding population of donor $\mathrm{CD} 11 \mathrm{~b}^{+} \mathrm{Gr}-\mathrm{1}^{\text {int }}$ MDSCs and abrogated by treating recipient animals with an anti-GR-1 MAb [83, 84].

Recent retrospective clinical data strongly support the beneficial immunologic effects of donor iNKT cells in the setting of allogeneic HSCT in humans. Chaidos et al. showed in a multivariate analysis that a higher graft iNKT cell dose was associated with a significantly lower risk of acute GvHD [85]. Similarly, Rubio et al. found that low peripheral blood $\mathrm{iNKT/T}$ cell ratios post-transplant were an independent factor associated with the occurrence of acute GvHD [86]. Furthermore, iNKT cell stimulation through liposomal $\alpha$ GalCer resulted in Treg expansion and protection from GvHD in animal models [87, 88]. Currently, a multicenter phase I/II clinical trial (NCT01379209) investigating liposomal $\alpha$-GalCer (RGI-2001) in patients undergoing myeloablative allogeneic HSCT is under way in order to evaluate the safety and efficacy of this concept.

TLI/ATG conditioning has been translated to the clinic for both GvHD prevention and induction of solid organ transplant 
tolerance. In the first trial at Stanford, 37 patients with hematological malignancies were treated with 10 doses of TLI and ATG [89•]. Importantly, most patients presented with advanced or refractory disease and were not eligible for conventional myeloablative conditioning due to age and comorbidities. Although $38 \%$ of patients received a matched unrelated graft, only $3 \%$ developed acute GvHD $\geq$ grade II with evidence for retained graft-versus-tumor activity. In this study, 12 of 16 patients with lymphoid malignant diseases in partial remission at time of transplantation subsequently converted to a complete remission. Interestingly, these results were associated with a Th2-biased cytokine profile and a reduced proliferative response of donor $\mathrm{CD}^{+} \mathrm{T}$ cells toward alloantigens. Kohrt et al. reported a follow-up of this study including a total of 111 patients all ineligible for conventional full-dose conditioning due to age or comorbidities [90]. Although 50 patients received a graft from an HLA-matched unrelated donor and 61 patients received a graft from a related donor, the probability of acute GvHD $\geq$ grade II by day 100 was as low as 10 and $2 \%$, respectively. Importantly, a relative increase of host iNKT cells in the peripheral blood during condition with TLI/ ATG was observed. Whereas advanced disease at time of transplantation was associated with a higher risk of progressive disease or relapse, achievement of complete chimerism predicted a more favorable outcome which leads to the intriguing question of whether donor lymphocyte infusions may promote graft-versus-tumor effects without inducing GvHD in the setting of TLI/ATG conditioning. This is of great importance as a relevant percentage of patients failed to convert to complete donor chimerism. Notably, 20 of 34 patients who achieved complete remission had clearing of tumor that was outside the field of TLI indicating sustained graftmediated antitumor activity. A multicenter study performed by the Gruppo Italiano Trapianti di Midollo investigated TLI/ATG conditioning in a similar population of 45 patients with lymphoid and myeloid malignancies confirming the tolerogenic properties and tolerability of this preparative regimen [91]. More recently, comparable results were published by Benjamin et al. who studied TLI/ATG conditioning in 61 patients for the treatment of myelodysplastic and myeloproliferative disorders [92]. Cumulative incidence of acute GvHD grades II-IV was as low as $14 \%$ with a 1-year non-relapse mortality (NRM) of only $7 \%$ although patient age ranged from 50 to 73 years. A randomized clinical trial has been performed in Belgium comparing TLI/ATG to fludarabine and TBI which demonstrated comparable overall survival outcomes confirming the low risk of acute GvHD and transplantrelated mortality although relapse was higher in patients conditioned with TLI/ATG [93]. TLI/ATG conditioning is characterized by a low non-relapse mortality with a decreased incidence of GvHD compared to established reduced intensity regimens making this approach suitable for older, heavily pretreated patients with comorbid medical conditions [94].
Beyond GvHD prevention, TLI/ATG has been shown to induce tolerance of the host toward solid organ transplants in both animal models and humans [78, 81, 95]. At Stanford, kidney transplant patients were treated with TLI/ATG conditioning following injection of $\mathrm{CD} 34^{+}$hematopoietic cells and $\mathrm{CD} 3^{+} \mathrm{T}$ cells from the same donor with the goal of long-term withdrawal of systemic immunosuppressive drugs [96]. Scandling et al. reported recently 38 patients that were treated with combined living donor kidney and HSCT after TLI/ATG conditioning. Persistent chimerism for at least 6 months was associated with successful complete withdrawal of immunosuppressive drugs in 16 of 22 matched patients without rejection episodes or kidney disease recurrence with up to 5 years follow-up. Importantly, no kidney graft loss or GvHD occurred with up to 14 years of observation which is improved compared to a cohort of kidney transplant recipients treated over the same time period without TLI/ATG conditioning and allogeneic HSCT [97].

Preclinical studies investigating TLI/ATG conditioning and the biology of iNKT cells paved the avenue for successful clinical translation to prevent GvHD and promote solid organ transplant tolerance without livelong immunosuppression.

\section{Challenges and Future Directions}

Several years have passed since the discovery of Treg and the first descriptions of their suppressive functions. Since then, Treg have been considered a possible therapeutic tool for immune-mediated diseases, and a number of clinical studies have been conducted to demonstrate their translational potential confirming many of the initial observations made in animal models. Preclinical studies widely demonstrated that Treg are able to ameliorate different autoimmune and alloimmune diseases in several models, but the road to clinical translation has presented many obstacles.

Human Treg are a rare population, and their paucity in the peripheral blood limits their clinical application. To overcome this issue, several studies suggested various methods for expansion of Treg that may occur directly in vivo or in vitro. In vivo administration of IL-2 is one of the widely used methods for Treg expansion. As discussed above, low-dose IL-2 treatment could preferentially expand Treg without expanding activated effector $\mathrm{T}$ cells [48], and Treg may also be expanded in vivo by iNKT $[83,84]$. Recently, the agonistic antibody of TNFRSF25 (also called Death receptor 3, DR3) has been reported as a potential reagent to selectively expand Treg in vivo [98]. TL1a (natural ligand of TNFRSF25) conjugated with $\operatorname{IgG}$ heavy chain has also been explored for in vivo activation and expansion of Treg [99]. We have recently found that a single injection of an agonistic anti-DR3 Mab to the donor can result in expansion of Treg and splenocytes from these animals result in dramatically reduced risk of GVHD compared to isotype-treated animals [100]. The 
precise mechanism of Treg expansion through TL1aTNFRSF25 signaling is still not fully understood. Another strategy for Treg-based therapy is the expansion of Treg ex vivo prior to their administration to patients. Ex vivo expansion of Treg with IL-2 and CD3/CD28 activation [101], TGF- $\beta$ [102], rapamycin [103], retinoic acid [104], and a histone deacetylase inhibitor [105] has all been reported. However, concerns about the activation/proliferation of nonTreg subsets including effector $\mathrm{T}$ cells persist. A clinical trial of ex vivo expanded human natural Treg using the combination of $\mathrm{CD} 3 / \mathrm{CD} 28$ activation and antigen presenting cells under GMP condition was also reported [106]. Although GMP sorting and culture are not easy for many institutions, expanded Treg may represent a potential treatment option for auto and alloimmune diseases refractory to conventional therapies. A brief summary of different methods for modulation and/or expansion of FoxP3 ${ }^{+}$Treg is shown in Fig. 1 .

Thus far, the adoptive transfer of purified populations of Treg has been mainly employed in allogeneic HSCT with the goal of GvHD suppression; however, the approaches have been different in terms of cell number, preparation, source, purity, and timing of treatment. Studies showed that Treg adoptive transfer is more effective if it precedes conventional T cell infusion $[107,108]$. We recently showed that third party FoxP3 $^{+}$Treg may be a potential alternative to donor-derived FoxP3 ${ }^{+}$Treg for GvHD suppression. Third party Treg are rejected in vivo in GvHD mouse model but exert their function in the early post-transplant phase [109]. Other studies reported that antigen-specific Treg can be in vitro primed and exert a specific suppressive activity that do not impact normal immune functions [110-112]; therefore, a better knowledge of the antigens that trigger autoimmune and alloimmune disease is required for the clinical application of these approaches.

Recent studies demonstrated that $\operatorname{Tr} 1$ cells can be induced not only in vitro, as above reported, but also in vivo [113]. IL10 is crucial for inducing Tr1 cells, and the rapamycin/IL-10 combination has been used to effectively induce tolerance to
Fig. 1 FoxP3 ${ }^{+}$Treg-based treatments of immune-mediated diseases. The different therapeutic approaches that involve directly or indirectly the use of $\mathrm{FoxP}^{+}$ Treg are shown. FoxP3 ${ }^{+}$Treg can be adoptively transferred in the patient when freshly isolated or after ex vivo expansion. Recent discoveries are now showing that other cell populations such iNKT cells or newly developed drugs can expand $\mathrm{FoxP}^{+}$Treg or modulate their function. Other approaches aim to selectively remove effector $\mathrm{T}$ cells sparing $\mathrm{FoxP}^{+}$Treg and favoring their in vivo function

\section{Fox $3^{+}$Treg based approaches for the treatment of immune-mediated diseases}

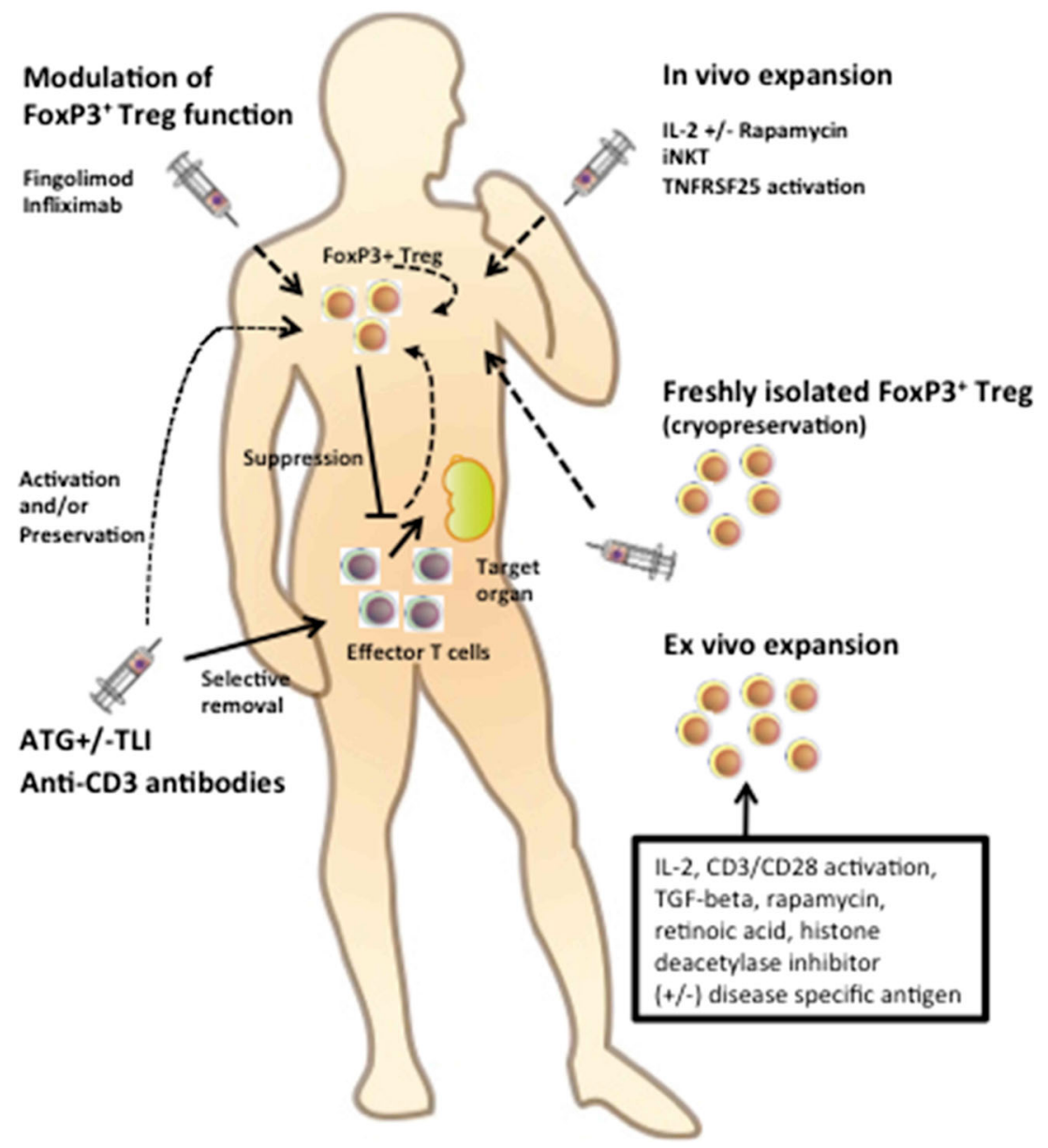


allogeneic islets in preclinical models of diabetes and to protect from autoimmunity promoting its use in the clinic [114, 115]. Furthermore, new discoveries on Tr1 cell phenotype will lead to a better cell selection and will facilitate clinical employment.

Finally, recent reports on the use of purified iNKT cells and their ability to expand Treg in vivo even when injected in small numbers are supportive of iNKT-based cellular therapy.

Regulatory $\mathrm{T}$ cells have tremendous promise, yet challenges persist on the road to clinical translation. Nonetheless, recent studies that expand our understanding of regulatory $\mathrm{T}$ cell biology and mechanisms of action are clarifying how these cells should be used and in which settings are the most suitable for effective clinical application.

Acknowledgments AP is supported by Fondazione Italiana per la Ricerca sul Cancro (FIRC), Società Italiana di Ematologia Sperimentale (SIES), Associazione Italiana contro le Leucemie-Linfomi e Mieloma (AIL), and a New Investigator Award from the American Society for Blood and Marrow Transplantation. DS is supported by a Dr. Mildred Scheel Postdoctoral Fellowship from the German Cancer Aid, a Young Investigator Award from the Stanford Institute for Immunity, Transplantation and Infection, and a New Investigator Award from the American Society for Blood and Marrow Transplantation. This work is also supported by Program Project Grants CA49605 and HL075462 and a R01 HL114591 from the National Cancer Institute and National Heart, Lung and Blood Institute.

Authorship AP, DS, and HN wrote the manuscript, and RSN helped write the manuscript and provided overall guidance.

\section{Compliance with Ethics Guidelines}

Conflict of Interest Antonio Pierini, Dominik Schneidawind, Hidekazu Nishikii, and Robert S. Negrin declare that they have no conflict of interest.

Human and Animal Rights and Informed Consent This article does not contain any previously unpublished studies with human or animal subjects performed by any of the authors.

\section{References}

Papers of particular interest, published recently, have been highlighted as:

- Of importance

1. Sakaguchi S, Yamaguchi T, Nomura T, Ono M. Regulatory T cells and immune tolerance. Cell. 2008;133:775-87.

2. Hori S, Nomura T, Sakaguchi S. Control of regulatory T cell development by the transcription factor Foxp3. Science. 2003;299:1057-61.

3. Bennett CL, Christie J, Ramsdell F, Brunkow ME, Ferguson PJ, Whitesell L, et al. The immune dysregulation, polyendocrinopathy, enteropathy, X-linked syndrome (IPEX) is caused by mutations of FOXP3. Nat Genet. 2001;27:20-1.
4. Brunkow ME, Jeffery EW, Hjerrild KA, Paeper B, Clark LB, Yasayko SA, et al. Disruption of a new forkhead/ winged-helix protein, scurfin, results in the fatal lymphoproliferative disorder of the scurfy mouse. Nat Genet. 2001;27:68-73.

5. Wildin RS, Ramsdell F, Peake J, Faravelli F, Casanova JL, Buist $\mathrm{N}$, et al. X-linked neonatal diabetes mellitus, enteropathy and endocrinopathy syndrome is the human equivalent of mouse scurfy. Nat Genet. 2001;27:18-20.

6. Sakaguchi S, Sakaguchi N, Asano M, Itoh M, Toda M. Immunologic self-tolerance maintained by activated $\mathrm{T}$ cells expressing IL-2 receptor alpha-chains (CD25). Breakdown of a single mechanism of self-tolerance causes various autoimmune diseases. J Immunol. 1995;155:1151-64.

7. Trenado A, Charlotte F, Fisson S, Yagello M, Klatzmann D, Salomon BL, et al. Recipient-type specific CD4+CD25+ regulatory $\mathrm{T}$ cells favor immune reconstitution and control graft-versushost disease while maintaining graft-versus-leukemia. J Clin Invest. 2003;112:1688-96.

8. Andersson J, Tran DQ, Pesu M, Davidson TS, Ramsey H, O'Shea $\mathrm{JJ}$, et al. CD4+ FoxP3+ regulatory T cells confer infectious tolerance in a TGF-beta-dependent manner. J Exp Med. 2008;205: 1975-81.

9. Collison LW, Workman CJ, Kuo TT, Boyd K, Wang Y, Vignali $\mathrm{KM}$, et al. The inhibitory cytokine IL-35 contributes to regulatory T-cell function. Nature. 2007;450:566-9.

10. Nakamura K, Kitani A, Strober W. Cell contact-dependent immunosuppression by $\mathrm{CD} 4(+) \mathrm{CD} 25(+)$ regulatory $\mathrm{T}$ cells is mediated by cell surface-bound transforming growth factor beta. J Exp Med. 2001;194:629-44.

11. Rubtsov YP, Rasmussen JP, Chi EY, Fontenot J, Castelli L, Ye X, et al. Regulatory T cell-derived interleukin-10 limits inflammation at environmental interfaces. Immunity. 2008;28:546-58.

12. Cao X, Cai SF, Fehniger TA, Song J, Collins LI, Piwnica-Worms $\mathrm{DR}$, et al. Granzyme B and perforin are important for regulatory $\mathrm{T}$ cell-mediated suppression of tumor clearance. Immunity. 2007;27: 635-46.

13. Deaglio S, Dwyer KM, Gao W, Friedman D, Usheva A, Erat A, et al. Adenosine generation catalyzed by CD39 and CD73 expressed on regulatory $\mathrm{T}$ cells mediates immune suppression. $\mathrm{J}$ Exp Med. 2007;204:1257-65.

14. Gondek DC, Lu LF, Quezada SA, Sakaguchi S, Noelle RJ. Cutting edge: contact-mediated suppression by CD4+CD25+ regulatory cells involves a granzyme B-dependent, perforinindependent mechanism. J Immunol. 2005;174:1783-6.

15. Grossman WJ, Verbsky JW, Tollefsen BL, Kemper C, Atkinson JP, Ley TJ. Differential expression of granzymes A and B in human cytotoxic lymphocyte subsets and T regulatory cells. Blood. 2004;104:2840-8.

16. Huang CT, Workman CJ, Flies D, Pan X, Marson AL, Zhou G, et al. Role of LAG-3 in regulatory T cells. Immunity. 2004;21: 503-13.

17. Wing K, Onishi Y, Prieto-Martin P, Yamaguchi T, Miyara M, Fehervari Z, et al. CTLA-4 control over Foxp3+ regulatory T cell function. Science. 2008;322:271-5.

18. Bacchetta R, de Waal Malefijt R, Yssel H, Abrams J, de Vries JE, Spits $\mathrm{H}$, et al. Host-reactive CD4+ and CD8+ T cell clones isolated from a human chimera produce IL-5, IL-2, IFN-gamma and granulocyte/macrophage-colony-stimulating factor but not IL-4. J Immunol. 1990;144:902-8.

19. Bacchetta R, Bigler M, Touraine JL, Parkman R, Tovo PA, Abrams J, et al. High levels of interleukin 10 production in vivo are associated with tolerance in SCID patients transplanted with HLA mismatched hematopoietic stem cells. J Exp Med. 1994;179:493-502. 
20. Groux H, O'Garra A, Bigler M, Rouleau M, Antonenko S, de Vries JE, et al. A CD4+ T-cell subset inhibits antigen-specific Tcell responses and prevents colitis. Nature. 1997;389:737-42.

21. Brun V, Bastian H, Neveu V, Foussat A. Clinical grade production of IL-10 producing regulatory Tr1 lymphocytes for cell therapy of chronic inflammatory diseases. Int Immunopharmacol. 2009;9: 609-13.

22. Brun V, Neveu V, Pers YM, Fabre S, Quatannens B, Bastian H, et al. Isolation of functional autologous collagen-II specific IL-10 producing Tr1 cell clones from rheumatoid arthritis blood. Int Immunopharmacol. 2011;11:1074-8.

23. Levings MK, Gregori S, Tresoldi E, Cazzaniga S, Bonini C, Roncarolo MG. Differentiation of $\mathrm{Tr} 1$ cells by immature dendritic cells requires IL-10 but not CD25+CD4+ Tr cells. Blood. 2005;105:1162-9.

24. Vieira PL, Christensen JR, Minaee S, O'Neill EJ, Barrat FJ, Boonstra A, et al. IL-10-secreting regulatory T cells do not express Foxp3 but have comparable regulatory function to naturally occurring CD4+CD25+ regulatory T cells. J Immunol. 2004;172: 5986-93.

25. Serafini G, Andreani M, Testi M, Battarra M, Bontadini A, Biral $\mathrm{E}$, et al. Type 1 regulatory $\mathrm{T}$ cells are associated with persistent split erythroid/lymphoid chimerism after allogeneic hematopoietic stem cell transplantation for thalassemia. Haematologica. 2009;94:1415-26.

26. Gagliani N, Magnani CF, Huber S, Gianolini ME, Pala M, LiconaLimon P, et al. Coexpression of CD49b and LAG-3 identifies human and mouse T regulatory type 1 cells. Nat Med. 2013;19: 739-46. This work defines the phenotypic characteristics of Tr1 cells.

27. Bacchetta R, Sartirana C, Levings MK, Bordignon C, Narula S, Roncarolo MG. Growth and expansion of human T regulatory type 1 cells are independent from TCR activation but require exogenous cytokines. Eur J Immunol. 2002;32:2237-45.

28. Bendelac A, Savage PB, Teyton L. The biology of NKT cells. Annu Rev Immunol. 2007;25:297-336.

29. Brennan PJ, Brigl M, Brenner MB. Invariant natural killer T cells: an innate activation scheme linked to diverse effector functions. Nat Rev Immunol. 2013;13:101-17.

30. Schneidawind D, Pierini A, Negrin RS. Regulatory T cells and natural killer T cells for modulation of GVHD following allogeneic hematopoietic cell transplantation. Blood. 2013;122:311621.

31. Cohen JL, Trenado A, Vasey D, Klatzmann D, Salomon BL. CD4(+)CD25(+) immunoregulatory T Cells: new therapeutics for graft-versus-host disease. J Exp Med. 2002;196:401-6.

32. Edinger M, Hoffmann P, Ermann J, Drago K, Fathman CG, Strober $\mathrm{S}$, et al. CD4+CD25+ regulatory $\mathrm{T}$ cells preserve graftversus-tumor activity while inhibiting graft-versus-host disease after bone marrow transplantation. Nat Med. 2003;9:1144-50.

33. Hoffmann P, Ermann J, Edinger M, Fathman CG, Strober S. Donor-type CD4(+)CD25(+) regulatory $\mathrm{T}$ cells suppress lethal acute graft-versus-host disease after allogeneic bone marrow transplantation. J Exp Med. 2002;196:389-99.

34. Taylor PA, Lees CJ, Blazar BR. The infusion of ex vivo activated and expanded CD4(+)CD25(+) immune regulatory cells inhibits graft-versus-host disease lethality. Blood. 2002;99:3493-9.

35. Trzonkowski P, Szarynska M, Mysliwska J, Mysliwski A. Ex vivo expansion of CD4(+)CD25(+) T regulatory cells for immunosuppressive therapy. Cytometry A. 2009; 75:175-88.

36. Di Ianni M, Falzetti F, Carotti A, Terenzi A, Castellino F, Bonifacio E, et al. Tregs prevent GVHD and promote immune reconstitution in HLA-haploidentical transplantation. Blood. 2011;117:3921-8. This study reports results of the first large clinical trial with FoxP3+ Treg adoptive transfer for GvHD prevention.
37. Martelli MF, Di Ianni M, Ruggeri L, Falzetti F, Carotti A, Terenzi A, et al. HLA-haploidentical transplantation with regulatory and conventional T-cell adoptive immunotherapy prevents acute leukemia relapse. Blood. 2014;124:638-44.

38. Brunstein CG, Miller JS, Cao Q, McKenna DH, Hippen KL, Curtsinger J, et al. Infusion of ex vivo expanded T regulatory cells in adults transplanted with umbilical cord blood: safety profile and detection kinetics. Blood. 2011;117:1061-70.

39. Theil A, Tuve S, Oelschlagel U, Maiwald A, Dohler D, Ossmann $\mathrm{D}$, et al. Adoptive transfer of allogeneic regulatory $\mathrm{T}$ cells into patients with chronic graft-versus-host disease. Cytotherapy. 2015;17:473-86.

40. Bacchetta R, Gregori S, Serafini G, Sartirana C, Schulz U, Zino E, et al. Molecular and functional characterization of allogantigenspecific anergic $\mathrm{T}$ cells suitable for cell therapy. Haematologica. 2010;95:2134-43.

41. Groux H, Bigler M, de Vries JE, Roncarolo MG. Interleukin-10 induces a long-term antigen-specific anergic state in human CD4+ T cells. J Exp Med. 1996;184:19-29.

42. Bacchetta R, Lucarelli B, Sartirana C, Gregori S, Lupo Stanghellini MT, Miqueu P, et al. Immunological Outcome in Haploidentical-HSC Transplanted Patients Treated with IL-10Anergized Donor T Cells. Front Immunol. 2014;5:16.

43. Martelli MF, Di Ianni M, Ruggeri L, Pierini A, Falzetti F, Carotti A, et al. "Designed" grafts for HLA-haploidentical stem cell transplantation. Blood. 2014;123:967-73.

44. Malek TR, Bayer AL. Tolerance, not immunity, crucially depends on IL-2. Nat Rev Immunol. 2004;4:665-74.

45. Nelson BH. IL-2, regulatory T cells, and tolerance. J Immunol. 2004;172:3983-8.

46. Soiffer RJ, Murray C, Gonin R, Ritz J. Effect of low-dose interleukin-2 on disease relapse after T-cell-depleted allogeneic bone marrow transplantation. Blood. 1994;84:964-71.

47. Zorn E, Nelson EA, Mohseni M, Porcheray F, Kim H, Litsa D, et al. IL-2 regulates FOXP3 expression in human CD4+CD25+ regulatory $\mathrm{T}$ cells through a STAT-dependent mechanism and induces the expansion of these cells in vivo. Blood. 2006;108:15719 .

48. Koreth J, Matsuoka K, Kim HT, McDonough SM, Bindra B, Alyea 3rd EP, et al. Interleukin-2 and regulatory T cells in graftversus-host disease. N Engl J Med. 2011;365:2055-66.

49. Matsuoka K, Koreth J, Kim HT, Bascug G, McDonough S, Kawano Y, et al. Low-dose interleukin-2 therapy restores regulatory $\mathrm{T}$ cell homeostasis in patients with chronic graft-versus-host disease. Sci Transl Med. 2013;5:179ra143.

50. Saadoun D, Rosenzwajg M, Joly F, Six A, Carrat F, Thibault V, et al. Regulatory T-cell responses to low-dose interleukin-2 in HCV-induced vasculitis. N Engl J Med. 2011;365:2067-77.

51. Hulme MA, Wasserfall CH, Atkinson MA, Brusko TM. Central role for interleukin-2 in type 1 diabetes. Diabetes. 2012;61:14-22.

52. Grinberg-Bleyer Y, Baeyens A, You S, Elhage R, Fourcade G, Gregoire S, et al. IL-2 reverses established type 1 diabetes in NOD mice by a local effect on pancreatic regulatory T cells. J Exp Med. 2010;207:1871-8.

53. Koulmanda M, Budo E, Bonner-Weir S, Qipo A, Putheti P, Degauque $\mathrm{N}$, et al. Modification of adverse inflammation is required to cure new-onset type 1 diabetic hosts. Proc Natl Acad Sci U S A. 2007;104:13074-9.

54. Tang Q, Adams JY, Penaranda C, Melli K, Piaggio E, Sgouroudis $\mathrm{E}$, et al. Central role of defective interleukin-2 production in the triggering of islet autoimmune destruction. Immunity. 2008;28: 687-97.

55. Rabinovitch A, Suarez-Pinzon WL, Shapiro AM, Rajotte RV, Power R. Combination therapy with sirolimus and interleukin-2 prevents spontaneous and recurrent autoimmune diabetes in NOD mice. Diabetes. 2002;51:638-45. 
56. Long SAM, Rieck S, Sanda JB, Bollyky PL, Samuels R, Goland A, et al. Rapamycin/IL-2 combination therapy in patients with type 1 diabetes augments Tregs yet transiently impairs beta-cell function. Diabetes. 2012;61:2340-8.

57. Baeyens A, Perol L, Fourcade G, Cagnard N, Carpentier W, Woytschak J, et al. Limitations of IL-2 and rapamycin in immunotherapy of type 1 diabetes. Diabetes. 2013;62:3120-31.

58. Hartemann A, Bensimon G, Payan CA, Jacqueminet S, Bourron $\mathrm{O}$, Nicolas $\mathrm{N}$, et al. Low-dose interleukin 2 in patients with type 1 diabetes: a phase $1 / 2$ randomised, double-blind, placebocontrolled trial. Lancet Diabetes Endocrinol. 2013;1:295-305.

59. Kim J, Lahl K, Hori S, Loddenkemper C, Chaudhry A, deRoos P, et al. Cutting edge: depletion of Foxp3+ cells leads to induction of autoimmunity by specific ablation of regulatory $\mathrm{T}$ cells in genetically targeted mice. J Immunol. 2009;183:7631-4.

60. Boehm F, Martin M, Kesselring R, Schiechl G, Geissler EK, Schlitt HJ, et al. Deletion of Foxp3 + regulatory T cells in genetically targeted mice supports development of intestinal inflammation. BMC Gastroenterol. 2012;12:97.

61. Lahl K, Loddenkemper C, Drouin C, Freyer J, Arnason J, Eberl G, et al. Selective depletion of Foxp3+ regulatory T cells induces a scurfy-like disease. J Exp Med. 2007;204:57-63.

62. Herold KC, Vignali DA, Cooke A, Bluestone JA. Type 1 diabetes: translating mechanistic observations into effective clinical outcomes. Nat Rev Immunol. 2013;13:243-56.

63. Marek-Trzonkowska N, Mysliwiec M, Dobyszuk A, Grabowska $\mathrm{M}$, Techmanska I, Juscinska J, et al. Administration of CD4+ $\mathrm{CD} 25$ highCD127- regulatory $\mathrm{T}$ cells preserves beta-cell function in type 1 diabetes in children. Diabetes Care. 2012;35:1817-20.

64. Herold KC, Hagopian W, Auger JA, Poumian-Ruiz E, Taylor L, Donaldson D, et al. Anti-CD3 monoclonal antibody in new-onset type 1 diabetes mellitus. N Engl J Med. 2002;346:1692-8.

65. Bisikirska B, Colgan J, Luban J, Bluestone JA, Herold KC. TCR stimulation with modified anti-CD3 mAb expands CD8+ T cell population and induces CD8+CD25+ Tregs. J Clin Invest. 2005;115:2904-13.

66. Herold KC, Gitelman SE, Ehlers MR, Gottlieb PA, Greenbaum CJ, Hagopian W, et al. Teplizumab (anti-CD3 mAb) treatment preserves C-peptide responses in patients with new-onset type 1 diabetes in a randomized controlled trial: metabolic and immunologic features at baseline identify a subgroup of responders. Diabetes. 2013;62:3766-74.

67. Herold KC, Gitelman SE, Willi SM, Gottlieb PA, Waldron-Lynch F, Devine L, et al. Teplizumab treatment may improve C-peptide responses in participants with type 1 diabetes after the new-onset period: a randomised controlled trial. Diabetologia. 2013;56:391400.

68. Sherry N, Hagopian W, Ludvigsson J, Jain SM, Wahlen J, Ferry Jr $\mathrm{RJ}$, et al. Teplizumab for treatment of type 1 diabetes (Protege study): 1-year results from a randomised, placebo-controlled trial. Lancet. 2011;378:487-97.

69. Kappos L, Antel J, Comi G, Montalban X, O'Connor P, Polman $\mathrm{CH}$, et al. Oral fingolimod (FTY720) for relapsing multiple sclerosis. N Engl J Med. 2006;355:1124-40.

70. Garris CS, Blaho VA, Hla T, Han MH. Sphingosine-1-phosphate receptor 1 signalling in $\mathrm{T}$ cells: trafficking and beyond. Immunology. 2014;142:347-53.

71. Liu G, Burns S, Huang G, Boyd K, Proia RL, Flavell RA, et al. The receptor S1P1 overrides regulatory T cell-mediated immune suppression through Akt-mTOR. Nat Immunol. 2009;10:769-77.

72. Brunkhorst R, Vutukuri R, Pfeilschifter W. Fingolimod for the treatment of neurological diseases-state of play and future perspectives. Front Cell Neurosci. 2014;8:283.

73. Valencia X, Stephens G, Goldbach-Mansky R, Wilson M, Shevach EM, Lipsky PE. TNF downmodulates the function of human CD4+CD25hi T-regulatory cells. Blood. 2006;108:25361.

74. Desreumaux P, Foussat A, Allez M, Beaugerie L, Hebuterne X, Bouhnik Y, et al. Safety and efficacy of antigen-specific regulatory T-cell therapy for patients with refractory Crohn's disease. Gastroenterology. 2012;143(1207-1217):e1201-1202.

75. Seino K, Harada M, Taniguchi M. NKT cells are relatively resistant to apoptosis. Trends Immunol. 2004;25:219-21.

76. Lan F, Zeng D, Higuchi M, Higgins JP, Strober S. Host conditioning with total lymphoid irradiation and antithymocyte globulin prevents graft-versus-host disease: the role of CD1-reactive natural killer T cells. Biol Blood Marrow Transplant. 2003;9:355-63.

77. Yao Z, Liu Y, Jones J, Strober S. Differences in Bcl-2 expression by T-cell subsets alter their balance after in vivo irradiation to favor CD4+Bcl-2hi NKT cells. Eur J Immunol. 2009;39:763-75.

78. Strober S, Modry DL, Hoppe RT, Pennock JL, Bieber CP, Holm $\mathrm{BI}$, et al. Induction of specific unresponsiveness to heart allografts in mongrel dogs treated with total lymphoid irradiation and antithymocyte globulin. J Immunol. 1984;132:1013-8.

79. Pillai AB, George TI, Dutt S, Strober S. Host natural killer T cells induce an interleukin-4-dependent expansion of donor CD4+ CD25+Foxp3 $+\mathrm{T}$ regulatory cells that protects against graftversus-host disease. Blood. 2009;113:4458-67.

80. Hongo D, Tang X, Baker J, Engleman EG, Strober S. Requirement for interactions of natural killer $\mathrm{T}$ cells and myeloid-derived suppressor cells for transplantation tolerance. Am J Transplant. 2014;14:2467-77.

81. Hongo D, Tang X, Dutt S, Nador RG, Strober S. Interactions between NKT cells and Tregs are required for tolerance to combined bone marrow and organ transplants. Blood. 2012;119: 1581-9.

82. van der Merwe M, Abdelsamed HA, Seth A, Ong T, Vogel P, Pillai AB. Recipient myeloid-derived immunomodulatory cells induce PD-1 ligand-dependent donor CD4+Foxp3+ regulatory $\mathrm{T}$ cell proliferation and donor-recipient immune tolerance after murine nonmyeloablative bone marrow transplantation. J Immunol. 2013;191:5764-76.

83. Schneidawind D, Pierini A, Alvarez M, Pan Y, Baker J, Buechele $\mathrm{C}$, et al. CD4+ invariant natural killer T cells protect from murine GVHD lethality through expansion of donor CD4+CD25+ FoxP3+ regulatory T cells. Blood. 2014;124:3320-8.

84. Schneidawind D, Baker J, Pierini A, Buechele C, Luong R H, Meyer E H, Negrin R S. Third party CD4+ invariant natural killer T cells protect from murine GVHD lethality. Blood. 2015.

85. Chaidos A, Patterson S, Szydlo R, Chaudhry MS, Dazzi F, Kanfer E, et al. Graft invariant natural killer T-cell dose predicts risk of acute graft-versus-host disease in allogeneic hematopoietic stem cell transplantation. Blood. 2012;119:5030-6.

86. Rubio MT, Moreira-Teixeira L, Bachy E, Bouillie M, Milpied P, Coman T, et al. Early posttransplantation donor-derived invariant natural killer T-cell recovery predicts the occurrence of acute graftversus-host disease and overall survival. Blood. 2012;120:2144 54.

87. Hirai T, Ishii Y, Ikemiyagi M, Fukuda E, Omoto K, Namiki M, et al. A novel approach inducing transplant tolerance by activated invariant natural killer T cells with costimulatory blockade. Am J Transplant. 2014;14:554-67.

88. Duramad O, Laysang A, Li J, Ishii Y, Namikawa R. Pharmacologic expansion of donor-derived, naturally occurring CD4(+)Foxp3(+) regulatory $\mathrm{T}$ cells reduces acute graft-versushost disease lethality without abrogating the graft-versusleukemia effect in murine models. Biol Blood Marrow Transplant. 2011;17:1154-68.

89. Lowsky R, Takahashi T, Liu YP, Dejbakhsh-Jones S, Grumet FC, Shizuru JA, et al. Protective conditioning for acute graft-versushost disease. N Engl J Med. 2005;353:1321-31. This manuscript 
reports results of the clinical trial with TLI/ATG conditioning for tolerance induction and GvHD prevention.

90. Kohrt HE, Turnbull BB, Heydari K, Shizuru JA, Laport GG, Miklos DB, et al. TLI and ATG conditioning with low risk of graft-versus-host disease retains antitumor reactions after allogeneic hematopoietic cell transplantation from related and unrelated donors. Blood. 2009;114:1099-109.

91. Messina G, Giaccone L, Festuccia M, Irrera G, Scortechini I, Sorasio R, et al. Multicenter experience using total lymphoid irradiation and antithymocyte globulin as conditioning for allografting in hematological malignancies. Biol Blood Marrow Transplant. 2012;18:1600-7.

92. Benjamin J, Chhabra S, Kohrt HE, Lavori P, Laport GG, Arai S, et al. Total lymphoid irradiation-antithymocyte globulin conditioning and allogeneic transplantation for patients with myelodysplastic syndromes and myeloproliferative neoplasms. Biol Blood Marrow Transplant. 2014;20:837-43.

93. Baron F, Zachee P, Maertens J, Kerre T, Ory A, Seidel L, et al. Non-myeloablative allogeneic hematopoietic cell transplantation following fludarabine plus 2 Gy TBI or ATG plus 8 Gy TLI: a phase II randomized study from the Belgian Hematological Society. J Hematol Oncol. 2015;8:4

94. Kohrt H, Lowsky R. Nonmyeloablative conditioning with total lymphoid irradiation and antithymocyte globulin: an update. Curr Opin Hematol. 2009;16:460-5.

95. Scandling JD, Busque S, Dejbakhsh-Jones S, Benike C, Millan MT, Shizuru JA, et al. Tolerance and chimerism after renal and hematopoietic-cell transplantation. N Engl J Med. 2008;358:3628 .

96. Scandling JD, Busque S, Dejbakhsh-Jones S, Benike C, Sarwal M, Millan MT, et al. Tolerance and withdrawal of immunosuppressive drugs in patients given kidney and hematopoietic cell transplants. Am J Transplant. 2012;12:1133-45.

97. Scandling JD, Busque S, Shizuru JA, Lowsky R, Hoppe R, Dejbakhsh-Jones $\mathrm{S}$, et al. Chimerism, graft survival, and withdrawal of immunosuppressive drugs in HLA matched and mismatched patients after living donor kidney and hematopoietic cell transplantation. Am J Transplant. 2015;15:695-704.

98. Schreiber TH, Wolf D, Tsai MS, Chirinos J, Deyev VV, Gonzalez L, et al. Therapeutic Treg expansion in mice by TNFRSF25 prevents allergic lung inflammation. J Clin Invest. 2010;120:362940.

99. Khan SQ, Tsai MS, Schreiber TH, Wolf D, Deyev VV, Podack ER. Cloning, expression, and functional characterization of TL1A-Ig. J Immunol. 2013;190:1540-50.

100. Kim BS, Nishikii H, Baker J, Pierini A, Schneidawind D, Pan Y, et al. Treatment with agonistic DR3 antibody results in expansion of donor Tregs and reduced graft-versus-host disease. Blood. 2015;124:546-57.

101. Hoffmann P, Eder R, Boeld TJ, Doser K, Piseshka B, Andreesen $\mathrm{R}$, et al. Only the CD45RA+ subpopulation of CD4+CD25high T cells gives rise to homogeneous regulatory T-cell lines upon in vitro expansion. Blood. 2006;108:4260-7.
102. Hippen KL, Merkel SC, Schirm DK, Nelson C, Tennis NC, Riley $\mathrm{JL}$, et al. Generation and large-scale expansion of human inducible regulatory $\mathrm{T}$ cells that suppress graft-versus-host disease. Am J Transplant. 2011;11:1148-57.

103. Battaglia M, Stabilini A, Roncarolo MG. Rapamycin selectively expands $\mathrm{CD} 4+\mathrm{CD} 25+$ FoxP $3+$ regulatory $\mathrm{T}$ cells. Blood. 2005; 105:4743-8.

104. Benson MJ, Pino-Lagos K, Rosemblatt M, Noelle RJ. All-trans retinoic acid mediates enhanced $\mathrm{T}$ reg cell growth, differentiation, and gut homing in the face of high levels of co-stimulation. J Exp Med. 2007;204:1765-74.

105. Tao R, de Zoeten EF, Ozkaynak E, Chen C, Wang L, Porrett PM, et al. Deacetylase inhibition promotes the generation and function of regulatory T cells. Nat Med. 2007;13:1299-307.

106. Hippen KL, Merkel SC, Schirm DK, Sieben CM, Sumstad D, Kadidlo DM, et al. Massive ex vivo expansion of human natural regulatory T cells (T(regs)) with minimal loss of in vivo functional activity. Sci Transl Med. 2011;3:83ra41.

107. Nguyen VH, Shashidhar S, Chang DS, Ho L, Kambham N, Bachmann M, et al. The impact of regulatory T cells on T-cell immunity following hematopoietic cell transplantation. Blood. 2008; 111:945-53.

108. Nguyen VH, Zeiser R, Dasilva DL, Chang DS, Beilhack A, Contag $\mathrm{CH}$, et al. In vivo dynamics of regulatory T-cell trafficking and survival predict effective strategies to control graft-versushost disease following allogeneic transplantation. Blood. 2007;109:2649-56.

109. Pierini A, Colonna L, Alvarez M, Schneidawind D, Nishikii H, Baker J, Pan Y, Florek M, Kim B S, Negrin R S. Donor requirements for regulatory $t$ cell suppression of murine graft-versus-host disease. J Immunol. 2015.

110. Masteller EL, Tang Q, Bluestone JA. Antigen-specific regulatory T cells-ex vivo expansion and therapeutic potential. Semin Immunol. 2006;18:103-10.

111. Tang Q, Henriksen KJ, Bi M, Finger EB, Szot G, Ye J, et al. In vitro-expanded antigen-specific regulatory $\mathrm{T}$ cells suppress autoimmune diabetes. J Exp Med. 2004;199:1455-65.

112. Veerapathran A, Pidala J, Beato F, Yu XZ, Anasetti C. Ex vivo expansion of human Tregs specific for alloantigens presented directly or indirectly. Blood. 2011;118:5671-80.

113. Roncarolo MG, Gregori S, Bacchetta R, Battaglia M. Tr1 cells and the counter-regulation of immunity: natural mechanisms and therapeutic applications. Curr Top Microbiol Immunol. 2014;380:39-68.

114. Battaglia M, Stabilini A, Draghici E, Migliavacca B, Gregori S, Bonifacio $\mathrm{E}$, et al. Induction of tolerance in type 1 diabetes via both CD4+CD25+ T regulatory cells and T regulatory type 1 cells. Diabetes. 2006;55:1571-80.

115. Battaglia M, Stabilini A, Draghici E, Gregori S, Mocchetti C, Bonifacio E, et al. Rapamycin and interleukin-10 treatment induces T regulatory type 1 cells that mediate antigen-specific transplantation tolerance. Diabetes. 2006;55:40-9. 